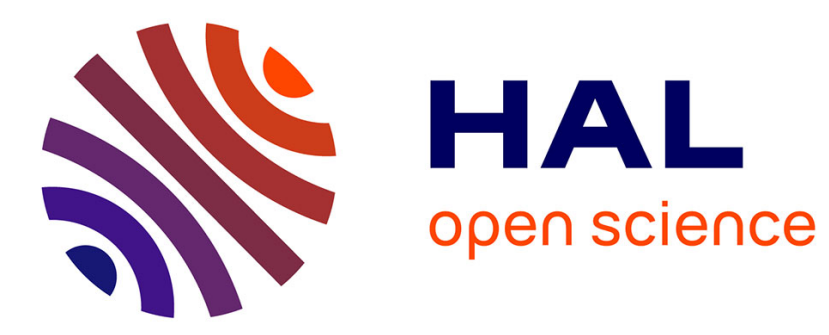

\title{
Designing metallic iron based water filters: Light from methylene blue discoloration
}

\author{
B.D. Btatkeu-K., J.B. Tchatchueng, C. Noubactep, Sabine Caré
}

\section{To cite this version:}

B.D. Btatkeu-K., J.B. Tchatchueng, C. Noubactep, Sabine Caré. Designing metallic iron based water filters: Light from methylene blue discoloration. Journal of Environmental Management, 2016, 166, pp.567-573. 10.1016/j.jenvman.2015.10.021 . hal-01248719

\section{HAL Id: hal-01248719 \\ https://hal-enpc.archives-ouvertes.fr/hal-01248719}

Submitted on 29 Apr 2019

HAL is a multi-disciplinary open access archive for the deposit and dissemination of scientific research documents, whether they are published or not. The documents may come from teaching and research institutions in France or abroad, or from public or private research centers.
L'archive ouverte pluridisciplinaire HAL, est destinée au dépôt et à la diffusion de documents scientifiques de niveau recherche, publiés ou non, émanant des établissements d'enseignement et de recherche français ou étrangers, des laboratoires publics ou privés. 


\title{
Designing metallic iron based water filters: Light from methylene blue discoloration
}

\author{
Btatkeu-K. B.D. ${ }^{(a, b)}$, Tchatchueng J.B. ${ }^{(a)}$, Noubactep C. ${ }^{(\mathrm{c}-\mathrm{e})}$, Caré S. ${ }^{(\mathrm{b})}$ \\ (a) Laboratory of Industrial and Pollution Chemistry, Department of Applied Chemistry, ENSAI, University of \\ Ngaoundéré, BP 455 Ngaoundéré, Cameroon; \\ (b) Université Paris-Est, Laboratoire Navier (UMR CNRS - IFSTTAR - ENPC), IFSTTAR, 6-8, av. Bd. Pascal, \\ F-77455 Marne-la-Vallée, France; \\ (c) Angewandte Geologie, Universität Göttingen, Goldschmidtstraße 3, D - 37077 Göttingen, Germany; \\ (d) Kultur und Nachhaltige Entwicklung CDD e.V., Postfach 1502, D - 37005 Göttingen, Germany; \\ (e) Comité Afro-européen - Avenue Léopold II, 41 - 5000 Namur, Belgium. \\ (*) Correspond author; e-mail: cnoubac@gwdg.de; Tel. +49 55139 3191, Fax. +49 551399379.
}

\begin{abstract}
Available water filtration systems containing metallic iron $\left(\mathrm{Fe}^{0}\right.$ filters) are pragmatically designed. There is a lack of sound design criteria to exploit the full potential of $\mathrm{Fe}^{0}$ filters. A science-based design relies on valuable information on processes within a $\mathrm{Fe}^{0}$ filter, including chemical reactions, hydrodynamics and their relation to the performance of the filter. The aim of this study was to establish a simple method to evaluate the initial performance of $\mathrm{Fe}^{0}$ filters. The differential adsorptive affinity of methylene blue (MB) onto sand and iron oxide is exploited to characterize the evolution of a $\mathrm{Fe}^{0} /$ sand system using the pure sand system as operational reference. Five systems were investigated for more than 70 days: pure sand, pure $\mathrm{Fe}^{0}, \mathrm{Fe}^{0} / \mathrm{sand}, \mathrm{Fe}^{0} / \mathrm{PM}$ and $\mathrm{Fe}^{0} / \mathrm{sand} / \mathrm{PM}$. Individual systems were characterized by the extent of changes in $\mathrm{pH}$ value, iron breakthrough, $\mathrm{MB}$ breakthrough and hydraulic conductivity. Results showed that for MB discoloration (i) pure sand was the most efficient system, (ii) hybrid systems were more sustainable than the pure $\mathrm{Fe}^{0}$ system, and (iii) the pores of used pumice are poorly interconnected. Characterizing the initial reactivity of $\mathrm{Fe}^{0}$ filters using $\mathrm{MB}$ discoloration has introduced a powerful tool for the exploration of various aspects of filter design.
\end{abstract}


Keywords: Contaminant removal, Frugal innovation, Selective adsorption, Water filtration, Zero-valent iron.

\section{$1 \quad$ Introduction}

The water remediation industry has developed a wide range of technologies for the removal of biological, chemical and physical contamination (Ali, 2014; Ghauch, 2015). Relevant treatment approaches include adsorption, chemical and enzymatic degradation, electrocoagulation, membrane filtration, photo-catalysis and oxidation. Adsorption on packed beds has been established as the most popular treatment process for water treatment at small scale (Dabrowski, 2001; Brunazzi et al., 2002; Ali, 2014). Activated carbon is the most common adsorbent for this process because of its effectiveness and versatility. However, the use of activated carbon in water treatment is still limited by its high cost and difficulty in regeneration (Ali, 2014). Accordingly a frugal adsorption science (Reardon, 2013) for safe drinking water is yet to be developed.

During the past two decades, the use of metallic iron $\left(\mathrm{Fe}^{0}\right)$ based materials $\left(\mathrm{Fe}^{0}\right.$ materials) as affordable alternative to commercially available adsorbents has become popular because of their low cost, ready availability and lack of toxicity (Ghauch, 2015; Guan et al. 2015). Although initially used as reducing agents, the unique remediation property of $\mathrm{Fe}^{0}$ materials arises from their ability to progressively produce highly reactive, iron hydroxides and oxides (Noubactep, 2010a; Noubactep, 2010b; Noubactep, 2013; Ghauch, 2015, Noubactep, 2015) that are excellent adsorbents for many chemicals (e.g. dyes, metals, nitrates, pesticides, pharmaceuticals, radionuclides) (Guan et al. 2015), pathogens (e.g. bacteria, viruses) (Bojic et al., 2001; You et al., 2005). These iron hydroxides with high specific surface area give $\mathrm{Fe}^{0}$ materials a broad range of applications as demonstrated in numerous laboratory treatability studies, pilot plant studies and full scale applications over the past two decades (O'Hannesin and Gillham, 1998; Wilkin et al., 2014, Ghauch 2015, Guan et al. 2015). 
Despite two decades of intensive research, there is still conflicting reports as to whether admixing $\mathrm{Fe}^{0}$ and inert materials (e.g. pumice termed as PM herein or sand) should be beneficial for the efficiency of resulting systems (Bi et al., 2009; Ulsamer, 2011 and refs. cited therein). The rationale for the enhanced efficiency of hybrid $\mathrm{Fe}^{0}$ systems over pure $\mathrm{Fe}^{0}$ systems is the volumetric expansive nature of metal corrosion (Pilling and Bedworth, 1923). Accordingly, in a pure $\mathrm{Fe}^{0}$ system, all particles induce volumetric expansion and clogging occurs very soon (Hussam, 2009; Noubactep and Caré, 2010; Noubactep et al., 2010). In contrast, in a 1:1 (vol/vol) $\mathrm{Fe}^{0}$ :sand system, only one half of available particles undergo volumetric expansion and clogging is delayed (Caré et al., 2013; Rahman et al., 2013; Domga et al., 2015). Recently, methylene blue (MB) was demonstrated an operational non reactive tracer for characterizing processes occurring in a $\mathrm{Fe}^{0} /$ sand systems in the initial stage of their operation (Miyajima, 2012; Miyajima and Noubactep, 2013; Btatkeu-K. et al., 2014; TepongTsindé et al. 2015).

The suitability of MB as operational non reactive tracer for the characterization of chemical processes occurring in $\mathrm{Fe}^{0}$ /sand systems arises from the following facts: (i) sand is an excellent adsorbent for cationic MB (Mitchell et al., 1955; Miyajima, 2012), (ii) cations ( $\mathrm{Fe}^{2+}$ and $\mathrm{Fe}^{3+}$ ) from $\mathrm{Fe}^{0}$ oxidative dissolution compete with $\mathrm{MB}$ for the sand surface (Btatkeu-K. et al., 2014) and (iii) once the surface of sand is (in-situ) coated by iron oxides, it is a poorer adsorbent for MB than virgin sand (Mitchell et al., 1955). In other words, comparing the discoloration of $\mathrm{MB}$ in a pure sand column and a $\mathrm{Fe}^{0} /$ sand column is a tool to assess the reactivity of the used $\mathrm{Fe}^{0}$ material. Similarly, because of the high $\mathrm{SiO}_{2}$-content of many $\mathrm{PM}$ samples (Derakhshan et al., 2013), it can be postulated that comparing the efficiency of the three systems pure $\mathrm{Fe}^{0}, \mathrm{Fe}^{0} /$ sand and $\mathrm{Fe}^{0} / \mathrm{PM}$ for $\mathrm{MB}$ discoloration will enable to assess the suitability of replacing compact sand by porous PM. It is postulated that PM will sustain hydraulic conductivity (permeability) of the filter (Rahman et al., 2013). 
The permeability of a system scales with its pore-size, which in turn is related to grain size, sorting, grain shape, grain packing, and the degree of cementation (Nur et al., 1998; Bland et al., 2009). The present study has used three different materials ( $\mathrm{Fe}^{0}, \mathrm{PM}$ and sand) to characterize solely the degree of cementation in $\mathrm{Fe}^{0}$-based filters. In such systems, an important inherent cause of porosity loss is in-situ generated gelatinous iron (hydr)oxides ('iron cement'). The porosity loss induced by 'iron cement' progressively occludes the pores between host grains (e.g. $\mathrm{Fe}^{0}$ and sand, $\mathrm{Fe}^{0}$ and $\mathrm{PM}$ ) (Miyajima 2012). To extend the knowledge of system permeability, the porosity of involved particles must be considered as well. For simplification $\mathrm{Fe}^{0}$ and sand are assumed compact (non porous) while PM is porous (Derakhshan et al., 2013).

The present work examines the feasibility of using porous PM to lengthen the service life of a $\mathrm{Fe}^{0} /$ sand system. $\mathrm{MB}$ is used as an operational non reactive tracer. Parallel experiments with pure sand, pure $\mathrm{Fe}^{0}, \mathrm{Fe}^{0} / \mathrm{sand}, \mathrm{Fe}^{0} / \mathrm{PM}$, and $\mathrm{Fe}^{0} / \mathrm{sand} / \mathrm{PM}$ were performed. The evolution of each system was characterized by measuring the time-dependent breakthrough of $\mathrm{H}^{+}(\mathrm{pH})$, iron, $\mathrm{MB}$, and changes of the hydraulic conductibility (permeability).

\section{$2 \quad$ Material and methods}

\section{$2.1 \quad$ Solutions}

\subsubsection{Methylene blue}

The used methylene blue (MB) (Basic Blue 9 from Merck) was of analytical grade. The working solution was $2.0 \mathrm{mg} \mathrm{L}^{-1}$. The solutions were prepared by diluting a $1000 \mathrm{mg} \mathrm{L}^{-1}$ stock solution. The stock solution was obtained by dissolving accurately weighted MB in distilled water. MB was chosen in this study because of its known differential adsorption onto iron oxides and sand (Mitchell et al., 1955).

\subsubsection{Iron}

A standard iron solution $(1000 \mathrm{mg} / \mathrm{L})$ from Baker $\mathrm{JT}^{\circledR}$ was used to calibrate the spectrophotometer used for analysis. All other chemicals used were of analytical grade. In 
preparation for spectrophotometric analysis, ascorbic acid (Janssen Chimica) was used to reduce $\mathrm{Fe}^{\mathrm{III}}$ in solution to $\mathrm{Fe}^{\mathrm{II}}$. 1,10 orthophenanthroline (ACROS Organics) was used as reagent for $\mathrm{Fe}^{\mathrm{II}}$ complexation. Other chemicals used in this study included $\mathrm{L}(+)$-ascorbic acid and L-ascorbic acid sodium acetate (sodium ascorbate).

\subsection{Solid materials}

$\mathrm{Fe}^{0}, \mathrm{PM}$ and sand are quantitatively available at many locations around the world and have been individually positively tested as MB discolouring agents (Mitchell et al., 1955; Noubactep, 2009; Derakhshan et al., 2013). Tab. 1 summarizes the point of zero charges $\left(\mathrm{pH}_{\mathrm{pzc}}\right)$ of metal oxides relevant for the discussion of the results of this study (Kosmulski, 2009). $\mathrm{Al}_{2} \mathrm{O}_{3}$ is considered because of its high content in the tested PM (12.33\%). Tab. 1 shows in particular that aluminium and iron hydroxides have the highest $\mathrm{pH}_{\mathrm{pzc}}(>8.0)$, making them positively charged over most $\mathrm{pH}$ ranges of this study $(\mathrm{pH}>7.0)$ and thus exhibiting repulsion toward positively charged MB (Miyajima, 2012).

\subsubsection{Metallic iron}

The used $\mathrm{Fe}^{0}$ was a commercial material from iPutech $\mathrm{GmbH}$ (Rheinfelden, Germany). The material was available as fillings with a particle size between 0.30 and $2.0 \mathrm{~mm}$. The material was fractionated by sieving. The fraction $0.4-0.8 \mathrm{~mm}$ was used without any further pretreatment. This fraction was close to the particle size $(0.50-1.00 \mathrm{~mm})$ of sand used to build the reactive zone. The average elemental composition of the materials as specified by the supplier was: C: $3.52 \%$; Si: $2.12 \%$; Mn: 0.93\%; Cr: 0.66\%.

\subsubsection{Pumice}

The used pumice (PM) originates from Lipari (Aeolian Islands, Sicily - Italy). Its mineralogical composition was determined as follows: $\mathrm{SiO}_{2}: 71.75 \% ; \mathrm{Al}_{2} \mathrm{O}_{3}: 12.33 \% ; \mathrm{K}_{2} \mathrm{O}$ : $4.47 \% ; \mathrm{Na}_{2} \mathrm{O}: 3.59 \% ; \mathrm{Fe}_{2} \mathrm{O}_{3}: 1.98 \%$; moreover it contains about $4 \%$ of bound water entrapped in the PM structure during the sudden cooling of magma and traces of other compounds (e.g. $\mathrm{CaO}, \mathrm{SO}_{3}, \mathrm{MgO}, \mathrm{TiO}_{2}, \mathrm{FeO}, \mathrm{MnO}, \mathrm{P}_{2} \mathrm{O}_{5}$ ). The material is characterized by 
uniform grain size distribution. The coefficient of uniformity $U$ is 1.4. The mean grain size $\left(\mathrm{d}_{50}\right)$ is about $0.3 \mathrm{~mm}$. This PM type has been chosen since it was the available fraction closest to $\mathrm{Fe}^{0}$ in dimension. The initial porosity $\Phi_{0}$ of the PM granular medium has been estimated to be $\Phi_{0}=73.3 \%$ and the inner porosity $\varphi_{\mathrm{pp}}$ of the PM (intra particular porosity $\varphi_{p p}$ ) to be 41 $\%$ (Bilardi et al., 2013).

\subsubsection{Sand}

The used sand was a natural material from Fontainebleau (France) purchased from Prolabo. The typical composition of this material is given as: $\mathrm{SiO}_{2}:>97.5 \%, \mathrm{Fe}_{2} \mathrm{O}_{3}:<0.17 \%, \mathrm{Al}_{2} \mathrm{O}_{3}$ : $<1.2 \%, \mathrm{Na}_{2} \mathrm{O}+\mathrm{K}_{2} \mathrm{O}:<1.0 \%, \mathrm{CaO}+\mathrm{MgO}:<0.1 \%$. Its elementary analysis was given by Jada and Akbour (2013) like: $\mathrm{Si}=45.03 \%, \mathrm{O}=52.18 \%, \mathrm{C}<0.3 \%, \mathrm{H}<0.3 \%, \mathrm{Ca}=100$ ppm, $\mathrm{Al}=185 \mathrm{ppm}, \mathrm{Mg}<10 \mathrm{ppm}, \mathrm{Na}<50 \mathrm{ppm}, \mathrm{Fe}=150 \mathrm{ppm}$. Its isoelectric point (IEP) as measured by microelectrophoresis is IEP $=2.44$ (Jada and Akbour, 2013). Fontainebleau sand was available in two fractions: (i) $\mathrm{d} \leq 0.5 \mathrm{~mm}$ and (ii) $\mathrm{d} \leq 5.0 \mathrm{~mm}$. The first fraction was sieved and particles ranging between 0.250 and $0.300 \mathrm{~mm}$ were retained for the first sand layer (fine sand - $\mathrm{H}_{3}$-sand, Fig. 1 and Tab. 2). The second fraction was sieved and particles ranging between 1.6 and $2.0 \mathrm{~mm}$ were retained for the second sand layer (coarse sand $-\mathrm{H}_{1}$ sand, Fig. 1 and Tab. 2). Another particle range of the second fraction $(0.50-1.00 \mathrm{~mm})$ was mixed to $\mathrm{Fe}^{0}$ and sand to build the reactive zone $\left(\mathrm{H}_{2}\right)$.

\subsection{Experimental configuration}

Plexiglas columns of $2.6 \mathrm{~cm}$ inner diameter and $50 \mathrm{~cm}$ length were used. The columns were intermittently charged with a gravity driven $2.0 \mathrm{mg} \mathrm{L}^{-1} \mathrm{MB}$ solution.

\subsection{MB discoloration}

From the bottom to the top, the columns were packed as follows: (i) fine sand $(0.250 \leq \mathrm{d}$ $(\mathrm{mm}) \leq 0.300)\left(\mathrm{H}_{3}=8.0 \mathrm{~cm}\right)$, (ii) a reactive zone made up of a $\mathrm{Fe}^{0} / \mathrm{sand}, \mathrm{Fe}^{0} / \mathrm{PM}$ or a $\mathrm{Fe}^{0} / \mathrm{sand} / \mathrm{PM}$ mixture $\left(\mathrm{H}_{2}\right.$, variable $)$, and (iii) a layer of coarse sand $(1.6 \leq \mathrm{d}(\mathrm{mm}) \leq 2.0)\left(\mathrm{H}_{1}\right.$, 
variable, but $\left.\mathrm{H}_{1}+\mathrm{H}_{2}=24.5 \mathrm{~cm}\right)$. The pure $\mathrm{Fe}^{0}$ system was tested as negative reference. The sand fraction used in the reactive zone was $0.50 \leq \mathrm{d}(\mathrm{mm}) \leq 1.0$. The first $17.5 \mathrm{~cm}$ at the top of the column were left free for the resting solution (Fig. 1 and Tab. 2). The total depth of the material was $32.5 \mathrm{~cm}$. The volumetric ratio of $\mathrm{Fe}^{0}$ in the reactive zone of hybrid systems $\left(\mathrm{H}_{2}\right)$ was $30 \%$. The $\mathrm{Fe}^{0} /$ sand/PM system contents $30 \% \mathrm{Fe}^{0}, 35 \%$ sand and $35 \%$ PM. Sixty-five g of iPutech $\mathrm{Fe}^{0}$ was used in each column. Its volume was used as unity; the resulting sand and PM masses are documented in Tab. 2.

Five filtration events were performed each week (daily from Monday to Friday). Each filtration event used $500 \mathrm{~mL}(0.5 \mathrm{~L})$ of the $\mathrm{MB}$ solution. This was to mimic the intermittent filtration with household filters for the daily water need in the developing world (Chiew et al., 2009). The whole experimental duration was 72 days corresponding to 63 filtration events. During this time, up to $31.5 \mathrm{~L} \mathrm{MB}$ solution were filtered through individual columns. The average time needed for the filtration of the first three $50 \mathrm{~mL}(150 \mathrm{~mL}$ in total) was used to calculate the flow velocity at each date. The measurement of the flow velocity was stopped when the time needed for the filtration of $50 \mathrm{~mL}$ was larger than $60 \mathrm{~min}$ ( 1 hour). The whole effluent for each filtration event was collected and analysed for MB. At certain time intervals iron and $\mathrm{H}^{+}$concentrations were determined. The temperature of the experiments was $22 \pm$ $2^{\circ} \mathrm{C}$, and the initial $\mathrm{pH}$ value was $6.8 \pm 0.2$ for all studies.

\subsection{Analytical methods}

$\mathrm{MB}$ and aqueous iron concentrations were determined by a Cary 50 UV-Vis spectrophotometer (Perkin Elmer Lambda $10 \mathrm{UV} / \mathrm{Vis}$ ) at a wavelength of $664.5 \mathrm{~nm}$ and 510.0 nm respectively. Cuvettes with $1.0 \mathrm{~cm}$ light path were used. The iron determination followed the 1,10 orthophenanthroline method (Fortune and Mellon, 1938). The spectrophotometer was calibrated for MB concentrations $\leq 2.5 \mathrm{mg} \mathrm{L}^{-1}$ and iron concentrations $\leq 10.0 \mathrm{mg} \mathrm{L}^{-1}$. The $\mathrm{pH}$ value was measured by combined glass electrodes (WTW Co., Germany).

\subsection{Expression of experimental results: $E$ values}


In order to characterize the magnitude of tested systems for $\mathrm{MB}$ discoloration, the discoloration efficiency (E) was calculated (Eq. 1). After the determination of the residual MB concentration $(\mathrm{C})$, the corresponding percent $\mathrm{MB}$ discoloration (E value) was calculated as:

$$
\mathrm{E}=\left[1-\left(\mathrm{C} / \mathrm{C}_{0}\right)\right] * 100 \%
$$

where $\mathrm{C}_{0}$ is the initial aqueous $\mathrm{MB}$ concentration $\left(2.0 \mathrm{mg} \mathrm{\textrm {L } ^ { - 1 }}\right)$, while $\mathrm{C}$ gives the $\mathrm{MB}$ concentration after the experiment.

The residual porosity $\left(\Phi / \Phi_{0}\right)$ is defined as the ratio of the porosity at time $t(\Phi)$ to the initial porosity $\Phi_{0} . \Phi / \Phi_{0}$ acts as an indicator of changes in the hydraulic conductivity and is given for individual systems (in \%) as the ratio of measured flow velocities (Eq. 2).

$$
\Phi / \Phi_{0}=100 * \mathrm{v} / \mathrm{v}_{0}
$$

where $\mathrm{v}$ and $\mathrm{v}_{0}$ are the water flow velocity at time $\mathrm{t}$ and $\mathrm{t}_{0}=0$ respectively.

\section{$3 \quad$ Results and discussion}

\section{1 pH value and iron release}

Figure 2a summarizes the results of the evolution of the $\mathrm{pH}$ value in the five systems. No clear trend in the evolution of $\mathrm{pH}$ could be noticed in all the systems. The initial $\mathrm{pH}$ value for the reference system (sand) and the $\mathrm{Fe}^{0}$ /sand system was comparatively low and closed to 7.0. This could be attributed to acidification due to dissolution of fine particles of sand (Kaplan et al., 2004). However, the subsequent $\mathrm{pH}$ increase is difficult to rationalize, especially as the $\mathrm{pH}$ of the reference system remained one of the highest for the rest of the experiment. All PMcontaining systems exhibited higher initial $\mathrm{pH}$ values, this can be rationalized by the $\mathrm{K}$ and $\mathrm{Na}$ contents $\left(\mathrm{K}_{2} \mathrm{O}: 4.47 \%, \mathrm{Na}_{2} \mathrm{O}: 3.59 \%\right)$.

In general, the solution $\mathrm{pH}$ affects both aqueous chemistry and surface binding sites of involved adsorbents. The main mechanism of MB discoloration by tested adsorbents is electrostatic interaction (Noubactep 2009). With increasing $\mathrm{pH}$ values, the concentration of $\mathrm{OH}^{-}$ions increases and the surface of the adsorbent become deprotonated. The result is a more negative charge favoring electrostatic attraction of cationic MB. Considering the point of zero 
charge of involved adsorbents (Tab. 1), one can argue that the best adsorbent for MB is sand $\left(\mathrm{SiO}_{2}\right)$. Accordingly tested $\mathrm{PM}$, with about $72 \% \mathrm{SiO}_{2}$ and a higher surface area, should be the best discolouring agent. The validity of this hypothesis (Hypothesis 1: PM is a better MB discolouring agent than sand) will be tested in the next section (MB discoloration).

The other decisive impact of the $\mathrm{pH}$ value is on the solubility (and thus the transport) of metallic ions (e.g. $\mathrm{Fe}^{\mathrm{II}}$ and $\mathrm{Fe}^{\mathrm{III}}$ species). Fig. 2a shows that the $\mathrm{pH}$ value in all systems is larger than 6.5. This is the domain were the solubility of iron is minimal (Noubactep. 2010a; and refs. cited therein). Rationally, if the system was at equilibrium, there should be no difference with regard to the iron concentration (which should be less than $1 \mathrm{mg} / \mathrm{L}$ ). In other words, observed differences (Fig. 2b) should be rationalized by other arguments, for instance, the flow velocity or the affinity of other materials for adsorbing Fe species. Fig. $2 b$ shows that iron release from the reference system was negligible. This observation is consistent with the mineralogical composition of Fontainebleau sand $\left(\mathrm{Fe}_{2} \mathrm{O}_{3}:<0.17 \%\right)$. The increasing order of the extent of iron release in the three other systems was: $\mathrm{Fe}^{0} / \mathrm{PM}=\mathrm{Fe}^{0} / \mathrm{sand} / \mathrm{PM}<\mathrm{Fe}^{0}<$ $\mathrm{Fe}^{0} /$ sand.

To be released from a column, iron species from $\mathrm{Fe}^{0}$ oxidative dissolution in the reactive zone $\left(\mathrm{H}_{2}\right.$, Fig. 1) have to migrate through the fine sand layer $\left(\mathrm{H}_{3}\right.$, Fig. 1). Due to the low solubility of iron for the investigated $\mathrm{pH}$ range $(\mathrm{pH}>6.0)$, in situ coating of the $\mathrm{H}_{3}$-sand will occur via adsorption or adsorptive precipitation (Miyajima, 2012). Additionally, iron may precipitate or adsorb onto iron aged oxides within the reactive zone $\left(\mathrm{H}_{2}\right)$. Fe removal by size-exclusion also occurs. In other words, the released iron is the excess that has not interacted within the $\mathrm{H}_{2}$ and $\mathrm{H}_{3}$ layers. Intuitively, given the inherent PM porosity, it would have been expected that more iron is released in the $\mathrm{Fe}^{0} / \mathrm{sand} / \mathrm{PM}$ system and less in the $\mathrm{Fe}^{0}$ /sand system. The fact that less iron was released in the both PM-containing systems than in the pure $\mathrm{Fe}^{0}$ system needs explanations. The most plausible explanation is that despite high porosity, the pores are not interconnected such that the residence time is larger in the PM-containing system. A larger 
residence time means more time for iron precipitation or low iron breakthrough. The validity of this hypothesis (Hypothesis 2: the PM pores are not interconnected) will be tested in the section on permeability loss.

\subsection{MB discoloration}

Figure 3 summarizes the result of $\mathrm{MB}$ discoloration (E values) in the reference system (sand) and the four $\mathrm{Fe}^{0}$-based systems. It is clear from Fig. 3 that the reference system was the most efficient at discolouring MB. The least efficient at discolouring $\mathrm{MB}$ is the $\mathrm{Fe}^{0} / \mathrm{sand}$ system; this corresponds to the system with the highest iron release, confirming that MB removal is coupled with iron precipitation (co-precipitation) (Noubactep, 2009). As discussed extensively elsewhere (Hussam, 2009; Miyajima, 2012; Bilardi et al., 2013), the apparent high efficiency of the pure $\mathrm{Fe}^{0}$ system (Fig. 3) is coupled to short-term permeability loss as presented below (section 3.3). As concerning the $\mathrm{Fe}^{0} / \mathrm{PM}$ system, Fig. 3 shows clearly that its efficiency was the second poorest; just the $\mathrm{Fe}^{0} /$ sand system was poorer (Fig. 3). Accordingly, Hypothesis 1 (PM is a better MB discolouring agent than sand) is apparently verified, due to differences in permeability.

Hypothesis 1 was somewhat faulty because the higher available surface area is not available for the same experimental duration and the same hydraulic conductivity (different residence times). In other words, properly discussing the validity of Hypothesis 1 requires both the consideration of the relative permeability of the two systems and the knowledge of the effective surface in both cases. This discussion is over the scope of the present study. It is sufficient to acknowledge that the results herein confirm the fact that designing an efficient filter is concealing (at least) two antagonistic views: (i) increased efficiency (higher surface area with PM), and (i) increased residence time (lower porosity but better drainage with sand) for the same hydraulic pressure (gravity). An additional essential fact to be considered is that iron corrosion is volumetric expansive in nature such that, for the same additive (e.g. sand), one should find the balance between increased efficiency (more $\mathrm{Fe}^{0}-$ less sand) and increased 
permeability (less $\mathrm{Fe}^{0}$ - more sand). Previous works, partly using gravity driven systems, have demonstrated that the optimal $\mathrm{Fe}^{0}$ volumetric ratio for sustainable filters is $25 \%$ (Miyajima, 2012; Miyajima and Noubactep, 2013; Btatkeu-K. et al., 2014).

The last important feature from Fig. 3 is the comparison of the $\mathrm{Fe}^{0} / \mathrm{sand}$ and the $\mathrm{Fe}^{0} / \mathrm{sand} / \mathrm{PM}$ systems. As pointed out already, $\mathrm{Fe}^{0} / \mathrm{sand}$ is the worst system at discolouring MB. Fig. 4 reveals that this system is more permeable than $\mathrm{Fe}^{0} / \mathrm{sand} / \mathrm{PM}$. The initial $\mathrm{v}_{0}$-values (Eq. 2) were similar. In other words, the main reason for the low efficiency of the $\mathrm{Fe}^{0} /$ sand system is the too short residence time for $\mathrm{MB} / \mathrm{iron}$ corrosion products interactions yielding coprecipitation. Moreover, rapidly migrating $\mathrm{Fe}^{\mathrm{II}}$ (and $\mathrm{Fe}^{\mathrm{III}}$ ) species have competed with $\mathrm{MB}$ for adsorption on sand in the layers $\mathrm{H}_{2}$ and $\mathrm{H}_{3}$. Once the sand was coated by iron oxides, its adsorptive affinity to MB was considerably weakened (Mitchell et al., 1955; Btatkeu-K. et al., 2014). In the $\mathrm{Fe}^{0} / \mathrm{sand} / \mathrm{PM}$ system, the low interconnectivity of porous $\mathrm{PM}$ has favoured a larger residence time and precipitation of iron oxides in the $\mathrm{H}_{2}$ layer. This has resulted in less $\mathrm{Fe}^{\mathrm{II}} / \mathrm{Fe}^{\mathrm{III}} / \mathrm{MB}$ competitions for adsorption onto $\mathrm{H}_{3}$-sand and less coating of $\mathrm{H}_{3}$-sand with iron oxides. Altogether, these results validate Hypothesis 2 (the PM pores are poorly interconnected) and recall that the relationship between porosity and permeability is not linear (Bland et al., 2009).

\subsection{Hydraulic conductivity}

The results presented in Fig. 4 clearly demonstrate that the reference system (sand in $\mathrm{H}_{2}$ ) was the most permeable for the whole duration of the experiment (absence of expansive corroding $\mathrm{Fe}^{0}$ ). The decreasing order of sustained hydraulic conductivity was: sand $>\mathrm{Fe}^{0} /$ sand $>\mathrm{Fe}^{0} / \mathrm{PM}$ $>\mathrm{Fe}^{0} / \mathrm{sand} / \mathrm{PM}>\mathrm{Fe}^{0}$. Thus the least permeable system was the pure $\mathrm{Fe}^{0}$ system $\left(100 \% \mathrm{Fe}^{0}\right)$. This behaviour is rationalized by the volumetric expansive nature of all $\mathrm{Fe}^{0}$ particles in the reactive zone (Fig. 1), which has rapidly filled the initial inter-particular porosity of the system (Caré et al, 2013; Rhaman et al, 2013; Domga et al., 2015). 
The lower permeability of the $\mathrm{Fe}^{0} / \mathrm{PM}$ system relative to the $\mathrm{Fe}^{0} /$ sand system is an evidence for the low interconnectivity of available pores. This evidence alone validates Hypothesis 2 . Using exactly the same PM tested here and different $\mathrm{Fe}^{0}$ and sand materials, Bilardi et al. (2013) reported on increased permeability of the $\mathrm{Fe}^{0} / \mathrm{PM}$ relative to the $\mathrm{Fe}^{0} /$ sand system. However, their columns were not gravity driven. Btatkeu-K et al. (2014) showed that gravity driven column experiments may resolve open questions from pumped experiments. In particular, they showed that the optimal $\mathrm{Fe}^{0} /$ sand ratio for sustainable filters was $25 / 75$, while pumped experiments just revealed that it was inferior to 40/60 (Miyajima, 2012; Miyajima and Noubactep, 2013). This result questions the suitability of accelerated conditions used to shorten the experimental duration in treatability tests using $\mathrm{Fe}^{0}$ (Noubactep, 2016).

\subsection{Discussion}

The major output of this study is that the question whether sand can be replaced by PM is not a no/yes question. Depending on the interconnectivity of a PM, it can be purposefully used to modify water flow velocity and optimized the treatment efficiency.

\subsubsection{Significance of results for the design of $\mathrm{Fe}^{0}$ filtration systems}

The technology of treating contaminated water by filtration on $\mathrm{Fe}^{0}$ packed beds has been largely tested and used during the past two decades (O’Hannesin and Gillham, 1998; Wilkin et al., 2014; Ghauch, 2015; Guan et al., 2015). Properly designing a Fe ${ }^{0}$ filter is finding the balance between four interdependent design factors: (i) the $\mathrm{Fe}^{0}$ intrinsic reactivity, (ii) the $\mathrm{Fe}^{0}$ longevity, (iii) the filter structure including shape and dimensions, and (iv) the hydraulic conductivity (permeability). However, current design formulas for $\mathrm{Fe}^{0}$ filters do not properly account for the major physical processes driving remediation: adsorption, co-precipitation and size-exclusion (Domga et al., 2015; Ghauch, 2015; Noubactep, 2015). All three processes are intimately related to the expansive nature of iron corrosion. The expansive corrosion products (iron oxides and hydroxides) are the primary cause of permeability loss (Noubactep, 2010a; Caré et al., 2013; Rahman et al., 2013). This crucial aspect has not been properly considered 
before. Rather, some models focused on secondary aspects like gas (mostly $\mathrm{H}_{2}$ ) accumulation or natural attenuation to design $\mathrm{Fe}^{0}$-based filtration systems (Zhang and Gillham, 2005; Henderson and Demond, 2011). However, all abiotic processes should first be properly considered before the contributions of biotic processes are properly discussed.

The prevailing paradigm for the design of $\mathrm{Fe}^{0}$ filters stipulates that the design is speciesdependent, the selective affinity being of redox nature (Guan et al. 2015). Accordingly, relevant chemically degradable pollutants are treated within properly designed $\mathrm{Fe}^{0}$ filters. However, pollutants without any redox properties have been quantitatively removed by $\mathrm{Fe}^{0}$ filters (Lai et al., 2006; Noubactep, 2009, Phukan, 2015; Phukan et al., 2015). Moreover, although the remediation process has been assumed to be the redox reactivity of $\mathrm{Fe}^{0}$, current design formulas are empirical (Ulsamer, (2011) and ref. cited therein). Recent works have recalled that there is no $\mathrm{Fe}^{0} / \mathrm{H}_{2} \mathrm{O}$ stability domain under natural conditions (Noubactep, 2013; Ghauch, 2015). Accordingly, all relevant processes coupled to the presence of $\mathrm{Fe}^{0}$ in water occur either (i) at the $\mathrm{Fe}^{0} / \mathrm{Fe}$-oxide interface, (ii) within the oxide scale on $\mathrm{Fe}^{0}$, or at the interface Fe-oxide/ $\mathrm{H}_{2} \mathrm{O}$ (Noubactep, 2015). In particular, the oxide scale on $\mathrm{Fe}^{0}$ is the site of several dynamic processes including: (i) the generation of nascent and very reactive $\mathrm{H} / \mathrm{H}_{2}$, (ii) the polymerization and precipitation of iron hydroxides and oxides, (iii) the crystallization of iron oxides (Sato, 1989; Sato, 2001; Noubactep et al., 2009; Noubactep, 2015; Noubactep, 2016). With regard to contaminant removal, these processes induced adsorption and coprecipitation of contaminants within the oxide scale, creating a chemical gradient for the diffusion of dissolved contaminants (Ghauch et al., 2011; Gheju, 2011; Gheju and Balcu, 2011). This is the removal mechanism of all contaminants, regardless from their redox properties (Ghauch, 2015; Noubactep, 2015; Noubactep, 2016). The real specificity of species for the $\mathrm{Fe}^{0} / \mathrm{H}_{2} \mathrm{O}$ system is the affinity to iron oxides: the ion-selectivity (Sato, 2001).

The present study has exploited the differential adsorptive affinity of methylene blue (MB) for sand and iron oxides to corroborate an experimental protocol for characterizing processes in 
$\mathrm{Fe}^{0} / \mathrm{H}_{2} \mathrm{O}$ systems. The trick is to investigate the time-dependent evolution of the $\mathrm{Fe}^{0} / \mathrm{sand} / \mathrm{H}_{2} \mathrm{O}$ system. The extent of MB (cationic) discoloration depends on the extent of iron corrosion (intrinsic reactivity of $\left.\mathrm{Fe}^{0}\right)$ which first produces concurrent species $\left(\mathrm{Fe}^{2+}, \mathrm{Fe}^{3+}\right)$ for adsorption sites on sand and later in situ coated sand with poorer adsorptive affinity for cationic MB (Mitchell et al. 1955; Miyajima, 2012; Phukan, 2015). This tool has already been used to characterize the reactivity of $\mathrm{Fe}^{0}$ materials, to determine the optimum $\mathrm{Fe}^{0} / \mathrm{sand}$ ratio for sustainable $\mathrm{Fe}^{0}$ filters (Tepong-Tsindé et al., 2015a and refs. cited therein) and to characterize the ion-selective nature of $\mathrm{Fe}^{0} / \mathrm{H}_{2} \mathrm{O}$ systems (Phukan, 2015; Phukan et al., 2015). MB discoloration by $\mathrm{Fe}^{0} / \mathrm{sand} / \mathrm{H}_{2} \mathrm{O}$ systems can be used to optimize other parameters of filter design including the temperature, the geochemical constituents (e.g. carbonates, chloride, dissolved $\mathrm{O}_{2}$, humic substances, nitrate, silicate, sulphate) (Tepong-Tsindé et al., 2015a), the bed thickness or the number of beds required, the suitability of further additives (e.g. granular activated carbon, $\mathrm{MnO}_{2}$ ) and the water flow rate (Tepong-Tsindé et al., 2015b).

\subsubsection{MB discoloration approach for a frugal innovation}

Considering the simplicity of the $\mathrm{Fe}^{0} / \mathrm{sand} / \mathrm{MB} / \mathrm{H}_{2} \mathrm{O}$ system, the reliability of obtained results and the affordability of the experimental design, it is postulated that $\mathrm{Fe}^{0} / \mathrm{sand} / \mathrm{dye} / \mathrm{H}_{2} \mathrm{O}$ systems will be decisive for a science-based design of $\mathrm{Fe}^{0}$ filters. $\mathrm{MB}$ has been positively tested as a non reactive indicator. Orange II (O-II) and reactive read 120 (RR120) have been positively tested as anionic dyes with more affinity to iron oxides (Phukan, 2015; Phukan et al., 2015). Thereby the differential behavior of both dyes due to steric effects (RR120 significantly larger in size than O-II) was documented (Phukan, 2015). Other dyes with differential adsorptive affinity to iron oxides and different molecular size can be tested in parallel experiments to better assess/discuss the ion-selectivity of the $\mathrm{Fe}^{0} / \mathrm{H}_{2} \mathrm{O}$ system. On the other hand by testing congeners of a selected dye (Imamura et al., 2002), the impact for various functional groups on the efficiency of $\mathrm{Fe}^{0}$ filters can be assessed. This ambitious research program needs only a UV/VIS spectrophotometer to be started. Leupin and Hug 
(2005) and Leupin et al. (2005) have shown that one can gain reliable and applicable results from column experiments using available commercial water bottles as reaction vessels (columns).

Another essential feature of the investigated system, making it affordable for not well equipped laboratories worldwide is the usage of gravity driven systems: no peristaltic pump is needed (no constant electricity source). Some solar batteries could be needed just for the spectro-photometrical determination of the dye concentration. This last aspect is essential for appropriate research in the developing world for at least two reasons: (i) it enables good research despite lack of continual electrical current and (ii) it shows that profound understanding of the chemistry of a system may enable the development of reliable but applicable and affordable experimental designs to solve complex problems. The results obtained by MB and summarized herein have resolved a 18-years-lasting discussion, whether admixing sand and $\mathrm{Fe}^{0}$ is useful for system's efficiency (Ulsamer, 2011). In this effort, a myriad of sophisticated analytical devices and expensive software packages have been used. The knowledge from $\mathrm{Fe}^{0} / \mathrm{sand} / \mathrm{dye} / \mathrm{H}_{2} \mathrm{O}$ systems could help planning experimental program and optimizing the interpretation of results from sophisticated analytical devices. In other words, the $\mathrm{Fe}^{0} / \mathrm{sand} / \mathrm{dye} / \mathrm{H}_{2} \mathrm{O}$ is complementary to available tools. All these opportunities should be used in a truly multi-disciplinary approach to exploit the huge potential of $\mathrm{Fe}^{0}$ filters for groundwater remediation, safe drinking water provision and wastewater treatment. Summarized, the development of the $\mathrm{Fe}^{0}$ filtration technology is a typical case where frugal science might sustain do-it-yourself devices (Reardon, 2013) for safe drinking water provision worldwide. Not only less equipped laboratories would produce first rate results for the scientific community but low-income communities would savor the prestige of solving the long lasting issue of safe drinking water provision on a self-reliance basis. 


\section{Conclusions}

The present study demonstrated the suitability of methylene blue (MB) as an efficient non reactive tracer to characterize the reactivity of $\mathrm{Fe}^{0} /$ sand systems. The results revealed that $\mathrm{MB}$ is an appropriate indicator for describing processes occurring within the $\mathrm{Fe}^{0} /$ sand system. In particular, the oxidative dissolution of metallic iron $\left(\mathrm{Fe}^{0}\right)$ yielding expansive corrosion products could be followed as well as the induced extent of permeability loss. These findings for the $\mathrm{Fe}^{0} /$ sand system could be extended to the $\mathrm{Fe}^{0} / \mathrm{PM}$ and the $\mathrm{Fe}^{0} / \mathrm{sand} / \mathrm{PM}$ systems and enabled the characterization of the importance of increased contact time for involved processes. This study delineates the potential of dye discoloration as an appropriate, inexpensive, accessible and low-cost indicator for a science based design of $\mathrm{Fe}^{0}$ filters (frugal innovation).

The methodology described in the present study can help in (i) selecting $\mathrm{Fe}^{0}$, (ii) optimizing operational conditions (e.g. water flow rate), (iii) investigating the impact of solution chemistry (e.g. co-ions, pH, dissolved organic matter), and (iv) optimizing all aspects of bed design (e.g. length, thickness). Once founded knowledge on all these aspects are available, fine-tuning investigations with relevant pollutants will be considered, e.g. on a site-specific basis.

\section{Acknowledgements}

Mohammed Saad (Leesu, Ecole des Ponts ParisTech, Marne La Vallée), Mehmet A. Oturan and Olévera-Vargas (LGE, Institute IFI, Marne la Vallée) are thanked for their assistance in shaping the experiments and analysing the data. Dr. Mohammad Azizur Rahman (ISU, Leibniz University, Hannover/Germany) is thanked for his valuable advice. For providing the iron material investigated in this study the authors would like to express their gratitude to iPutec GmbH (Rheinfelden, Germany). The PM sample was provided by the Poalo Calabrò (Mediterranean University of Reggio Calabria, Italy). This work was partly supported by the "Service de Coopération et d'Action Culturelle" (SCAC) from the France Embassy in 
Yaoundé (Cameroun). The manuscript was improved by the insightful comments of anonymous reviewers from Journal of Environmental Management..

\section{References}

Ali, I. 2014. Water treatment by adsorption columns: Evaluation at ground level, Sep. Purif. Rev. 43, 175-205.

Bilardi, S., Calabrò, P.S., Caré, S., Moraci, N., Noubactep, C. 2013. Effect of pumice and sand on the sustainability of granular iron beds for the removal of $\mathrm{Cu}^{\mathrm{II}}, \mathrm{Ni}^{\mathrm{II}}$, and $\mathrm{Zn}^{\mathrm{II}}$, Clean - Soil, Air, Water 41, 835-843.

Bland, P.A., Jackson, M.D., Coker, R.F., Cohen, B.A., Webber, J.B.W., Lee, M.R., Duffy, C.M., Chater, R.J., Ardakani, M.G., McPhail, D.S., McComb, D.W., Benedix, G.K. 2009. Why aqueous alteration in asteroids was isochemical: High porosity \# high permeability. Earth Planet. Sci. Lett. 287, 559-568.

Bojic, A., Purenovic, M., Kocic, B., Perovic, J., Ursic-Jankovic, J., Bojic, D. 2001. The inactivation of escherichia coli by microalloyed aluminium based composite. Facta universitatis - Phys. Chem. Technol. 2, 115-124.

Brunazzi, E., Nardini, G., Paglianti, A. 2002. An economical criterion for packed absorption column design. Chem. Biochem. Eng. Quart. 15, 199-206.

Btatkeu-K., B.D., Olvera-Vargas, H., Tchatchueng, J.B., Noubactep, C., Caré, S. 2014. Determining the optimum $\mathrm{Fe}^{0}$ ratio for sustainable granular $\mathrm{Fe}^{0} /$ sand water filters. Chem. Eng. J. 247, 265-274.

Caré, S., Crane, R., Calabro, P.S., Ghauch, A., Temgoua, E., Noubactep, C. 2013. Modelling the permeability loss of metallic iron water filtration systems. Clean - Soil, Air, Water $41,275-282$.

Chiew, H., Sampson, M.L., Huch, S., Ken, S., Bostick, B.C. 2009. Effect of groundwater iron and phosphate on the efficacy of arsenic removal by iron-amended biosand filters. Environ. Sci. Technol. 43, 6295-6300. 
Dabrowski, A. 2001. Adsorption - from theory to practice. Adv. Colloid Interf. Sci. 93, 135224.

Derakhshan, Z., Baghapour, M.A., Ranjbar, M., Faramarzian, M. 2013. Adsorption of methylene blue dye from aqueous solutions by modified pumice stone: Kinetics and equilibrium studies. Health Scope 2, 136-44.

Domga, R., Togue-Kamga, F., Noubactep, C., Tchatchueng, J.B. 2015. Discussing porosity loss of $\mathrm{Fe}^{0}$ packed water filters at ground level. Chem. Eng. J. 263, 127-134.

Fortune, W.B., Mellon, M.G. 1938. Determination of iron with o-phenanthroline: a spectrophotometric study. Ind. Eng. Chem., Anal. Ed. 10, 60-64.

Ghauch, A. 2015. Iron-based metallic systems: An excellent choice for sustainable water treatment. Freiberg Online Geosci. 38, 80 pp.

Ghauch, A., Abou Assi, H., Baydoun, H., Tuqan, A.M., Bejjani, A. 2011. Fe ${ }^{0}$-based trimetallic systems for the removal of aqueous diclofenac: Mechanism and kinetics. Chem. Eng. J. 172, 1033-1044.

Gheju, M. 2011. Hexavalent chromium reduction with zero-valent iron (ZVI) in aquatic systems. Water Air Soil Pollut. 222, 103-148.

Gheju, M., Balcu, I. 2011. Removal of chromium from $\mathrm{Cr}(\mathrm{VI})$ polluted wastewaters by reduction with scrap iron and subsequent precipitation of resulted cations. J. Hazard. Mater. 196, 131-138.

Guan, X., Sun, Y., Qin, H., Li, J., Lo, I.M.C., He, D., Dong, H. 2015. The limitations of applying zerovalent iron technology in contaminants sequestration and the corresponding countermeasures: The development in zero-valent iron technology in the last two decades (1994-2014). Water Res. 75, 224-248.

Henderson, A.D., Demond, A.H. 2011. Impact of solids formation and gas production on the permeability of ZVI PRBs. J. Environ. Eng. 137, 689-696. 
Hussam, A. 2009. Contending with a development disaster: SONO filters remove arsenic from well water in Bangladesh. Innovations 4, 89-102.

Imamura, K., Ikeda, E., Nagayasu, T., Sakiyama, T., Nakanishi, K. 2002. Adsorption behavior of methylene blue and its congeners on a stainless steel surface. J. Colloid Interf. Sci. ence $245,50-57$.

Jada, A., Akbour, R.A. 2013. Adsorption and removal of organic dye at quartz sand-water interface. Oil Gas Sci. Technol., doi: 10.2516/ogst/2013169.

Kaplan, D.I., Gilmore, T.J. 2004 Zero-valent iron removal rates of aqueous Cr(VI) measured under flow conditions. Water Air Soil Pollut. 155, 21-33.

Kosmulski, M. 2009.Compilation of PZC and IEP of sparingly soluble metal oxides and hydroxides from literature. Adv. Colloid Interf. Sci. 152, 14-25.

Lai, K.C.K., Lo, I.M.C., Birkelund, V., Kjeldsen, P. 2006. Field monitoring of a permeable reactive barrier for removal of chlorinated organics. J. Environ. Eng. 132, 199-210.

Leupin, O.X., Hug, S.J. 2005. Oxidation and removal of arsenic (III) from aerated groundwater by filtration through sand and zero-valent iron. Water Res. 39, 1729740.

Leupin, O.X., Hug, S.J., Badruzzaman, A.B.M. 2005. Arsenic removal from Bangladesh tube well water with filter columns containing zerovalent iron filings and sand. Environ. Sci. Technol. 39, 8032-8037.

Mitchell, G., Poole, P., Segrove, H.D. 1955. Adsorption of methylene blue by high-silica sands. Nature 176, 1025-1026.

Miyajima, K. 2012. Optimizing the design of metallic iron filters for water treatment. Freiberg Online Geosci. 32, 60 pp.

Miyajima, K., Noubactep, C. 2013. Impact of $\mathrm{Fe}^{0}$ amendment on methylene blue discoloration by sand columns. Chem. Eng. J. 217, 310-319. 
Noubactep, C. 2009. Characterizing the discoloration of methylene blue in $\mathrm{Fe}^{0} / \mathrm{H}_{2} \mathrm{O}$ systems. J. Hazard. Mater. 166, 79-87.

Noubactep, C., Schöner, A., Woafo, P. 2009. Metallic iron filters for universal access to safe drinking water. Clean Soil, Air, Water 37, 930-937.

Noubactep, C. 2010a. Metallic iron for safe drinking water worldwide. Chem. En. J. 165, $740-749$.

Noubactep, C. 2010b. The suitability of metallic iron for environmental remediation. Environ. Progr. 29, 286-291.

Noubactep, C., Caré, S. 2010. Dimensioning metallic iron beds for efficient contaminant removal. Chem. Eng. J. 163, 454-460.

Noubactep, C., Caré, S., Togue-Kamga, F., Schöner, A., Woafo, P. 2010. Extending service life of household water filters by mixing metallic iron with sand. Clean - Soil, Air, Water 38, 951-959.

Noubactep, C. 2013. Metallic iron for water treatment: A critical review. Clean - Soil, Air, Water $41,702-710$

Noubactep, C. 2015. Metallic iron for environmental remediation: A review of reviews. Water Res. 85, 114-123.

Noubactep C. 2016. Designing metallic iron packed-beds for water treatment: A critical review. Clean - Soil, Air, Water, doi:10.1002/clen.201400304.

Nur, A., Mavko, G., Dvorkin, J., Galmudi, D. 1998. Critical porosity; a key to relating physical properties to porosity in rocks. The Leading Edge 17, 357-362.

O`Hannesin S.F., Gillham, R.W. 1998. Long-term performance of an in situ "iron wall" for remediation of VOCs. Ground Water 36, 164-170.

Phukan, M. 2015, Characterizing the ion selective nature of $\mathrm{Fe}^{0}$-based systems using azo dyes: batch and column experiments. Freiberg Online Geosci. 42, 60 pp. 
Phukan, M., Noubactep, C., Licha, T. 2015. Characterizing the ion-selective nature of $\mathrm{Fe}^{0}$ based filters using azo dyes. Chem. Eng. J. 259, 481-491.

Pilling, N.B., Bedworth, R.E. 1923. The oxidation of metals at high temperatures. J. Inst. Met. 29, 529-591.

Rahman M.A., Karmakar S., Salama, H., Gactha-Bandjun, N., Btatkeu-K. B.D., Noubactep, C. 2013. Optimising the design of $\mathrm{Fe}^{0}$-based filtration systems for water treatment: The suitability of porous iron composites. J. Appl. Solution Chem. Model. 2, 165177.

Reardon, S. 2013. Frugal science gets DIY diagnostics to world's poorest. New Scientist 219, 20-21.

Sato, N. 1989. Whitney Award Lecture: Toward a more fundamental understanding of corrosion processes. Corrosion 45, 354-368.

Sato, N. 2001. Surface oxides affecting metallic corrosion. Corros. Rev. 19, 253-272.

Saywell, L.G., Cunningham, B.B. 1937. Determination of iron: colorimetric o-phenanthroline method. Ind. Eng. Chem., Anal. Ed. 9, 67-69.

Tepong-Tsindé, R., Phukan, M., Nassi, A., Noubactep, C., Ruppert, H. 2015a. Validating the efficiency of the MB discoloration method for the characterization of $\mathrm{Fe}^{0} / \mathrm{H}_{2} \mathrm{O}$ systems using accelerated corrosion by chloride ions. Chem. Eng. J. 279, 353-362.

Tepong-Tsindé, R., Crane, R., Noubactep, C., Nassi, A., Ruppert, H. 2015b. Testing metallic iron filtration systems for decentralized water treatment at pilot scale. Water 7, 868897.

Ulsamer, S. 2011. A model to characterize the kinetics of dechlorination of tetrachloroethylene and trichloroethylene by a zero valent iron permeable reactive barrier, Master thesis, Worcester Polytechnic Institute 73 pp 
Wilkin, R.T., Acree, S.D., Ross, R.R., Puls, R.W., Lee, T.R., Woods, L.L. 2014. Fifteen-year assessment of a permeable reactive barrier for treatment of chromate and trichloroethylene in groundwater. Sci. Tot. Environ. 468-469, 186-194.

You, Y., Han, J., Chiu, P.C., Jin, Y. 2005. Removal and inactivation of waterborne viruses using zerovalent iron. Environ. Sci. Technol. 39, 9263-9269.

Zhang, Y., Gillham, R.W. 2005. Effects of gas generation and precipitates on performance of $\mathrm{Fe}^{\circ}$ PRBs. Ground Water 43, 113-121. 
Table 1: Point of zero charge $\left(\mathrm{pH}_{\mathrm{pzc}}\right)$ of minerals used to discuss $\mathrm{MB}$ discoloration. Data from Kosmulski (2009).

\begin{tabular}{|c|c|c|}
\hline \multicolumn{2}{|c|}{ Mineral } & \multirow[t]{2}{*}{$\mathbf{p H} H_{p z c}$} \\
\hline Name & Formula & \\
\hline Aluminum oxide & $\mathrm{Al}_{2} \mathrm{O}_{3}$ & $8.5 \pm 1.5$ \\
\hline Hydrous ferric oxide & $\mathrm{Fe}_{2} \mathrm{O}_{3} \cdot \mathrm{H}_{2} \mathrm{O}_{\text {(amorphous) }}$ & $8.7 \pm 0.1$ \\
\hline Goethite & $\alpha-\mathrm{FeOOH}$ & $6.6 \pm 2.6$ \\
\hline Hematite & $\alpha-\mathrm{Fe}_{2} \mathrm{O}_{3}$ & $6.1 \pm 1.5$ \\
\hline Sand (amorphous) & $\mathrm{SiO}_{2}$ & $2.1 \pm 1.0$ \\
\hline
\end{tabular}


Table 2: Experimental design for the characterization of MB discoloration. Each $\mathrm{Fe}^{0}$-based system contains $65 \mathrm{~g}$ of $\mathrm{Fe}^{0}$ corresponding to a volumetric ratio of $30 \%$. The volumetric ratio of each additive in the $\mathrm{Fe}^{0} / \mathrm{sand} / \mathrm{PM}(\mathrm{PM}=$ pumice $)$ system is $35 \% . \mathrm{H}_{1}$ is the coarse sand layer, $\mathrm{H}_{2}$ the reactive zone (containing $\mathrm{Fe}^{0}$ ) and $\mathrm{H}_{3}$ the fine sand layer.

\begin{tabular}{|c|c|c|c|c|c|c|c|c|}
\hline System & $\begin{array}{c}\text { Sand } \\
(\mathrm{g})\end{array}$ & $\begin{array}{l}\text { PM } \\
(\mathrm{g})\end{array}$ & $\begin{array}{l}\mathbf{F e}^{\mathbf{0}} \\
(\mathrm{g})\end{array}$ & $\begin{array}{c}\mathbf{F e}^{\mathbf{0}} \\
(\mathrm{wt} \%)\end{array}$ & $\begin{array}{l}\text { Sand } \\
(\mathrm{wt} \%)\end{array}$ & $\begin{array}{c}\mathbf{H}_{1} \\
(\mathrm{~cm})\end{array}$ & $\begin{array}{r}\mathbf{H}_{2} \\
(\mathrm{~cm})\end{array}$ & $\begin{array}{r}\mathbf{H}_{3} \\
(\mathrm{~cm})\end{array}$ \\
\hline Sand & 63.9 & 0.0 & 0.0 & 0.0 & 100 & 21.2 & 3.3 & 8.0 \\
\hline $\operatorname{Iron}\left(\mathrm{Fe}^{\mathbf{0}}\right)$ & 0.0 & 0.0 & 65.0 & 100 & 0.0 & 21.2 & 3.3 & 8.0 \\
\hline $\mathrm{Fe}^{0} / \mathrm{sand}$ & 63.9 & 0.0 & 65.0 & 50.4 & 49.6 & 14.7 & 9.8 & 8.0 \\
\hline $\mathrm{Fe}^{0} / \mathrm{PM}$ & 0.0 & 24.1 & 65.0 & 73.0 & 0.0 & 13.5 & 11.0 & 8.0 \\
\hline $\mathrm{Fe}^{0} / \mathrm{sand} / \mathrm{PM}$ & 31.6 & 11.7 & 65.0 & 60.0 & 29.2 & 13.5 & 11.0 & 8.0 \\
\hline
\end{tabular}


Figure 1: Experimental set up

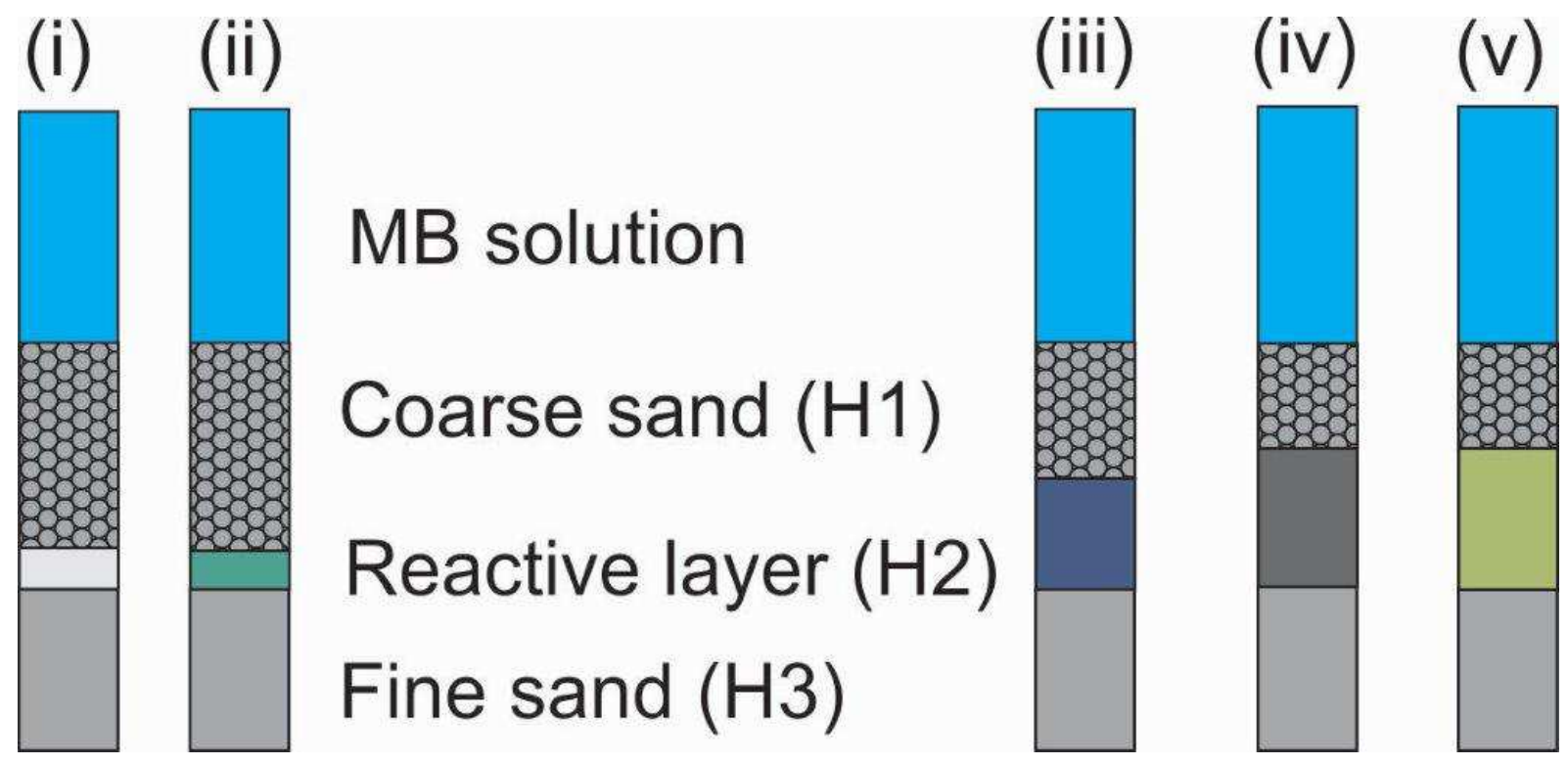


Fig. 2: pH and iron breakthrough
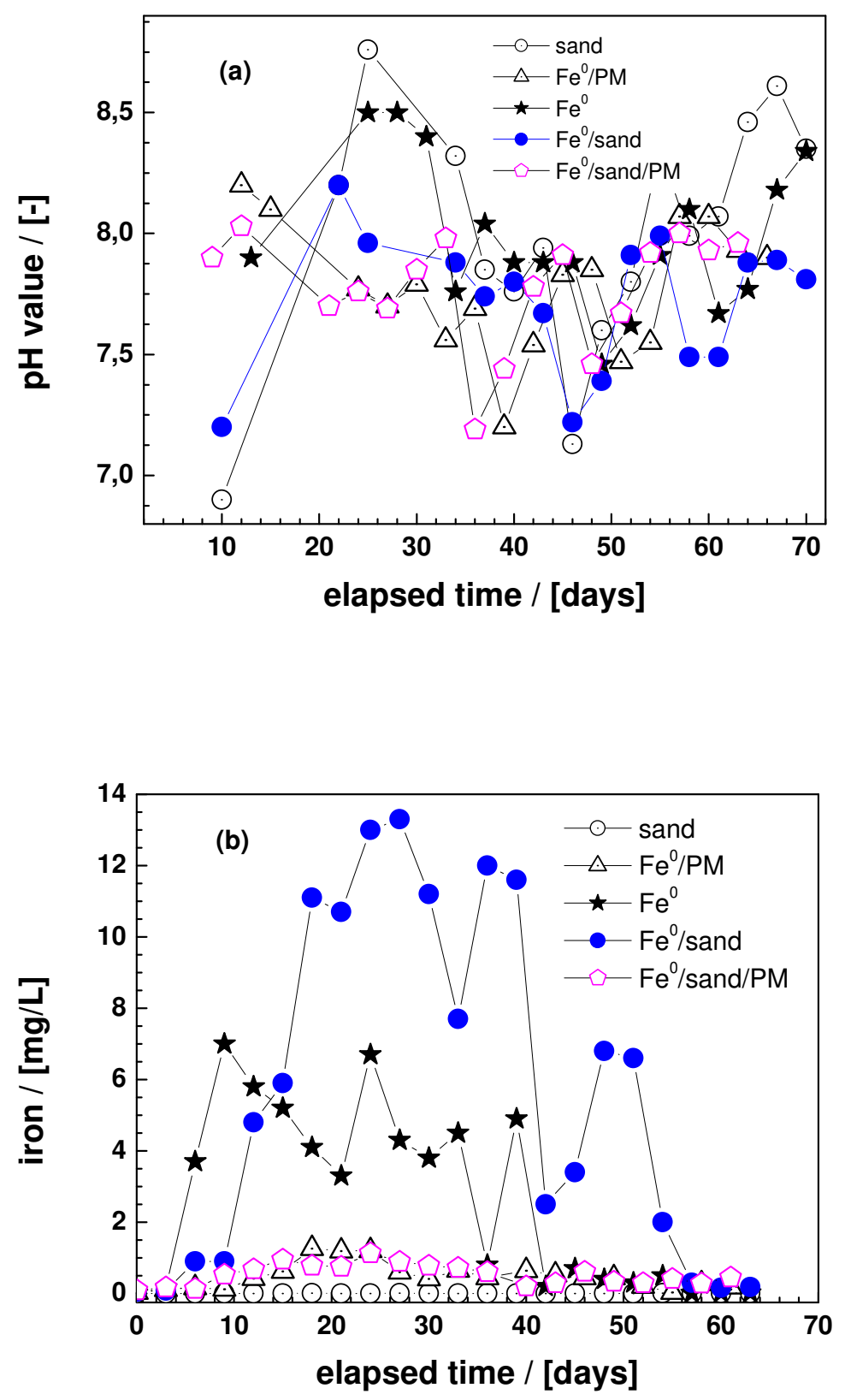
Fig. 3: Discoloration efficiency

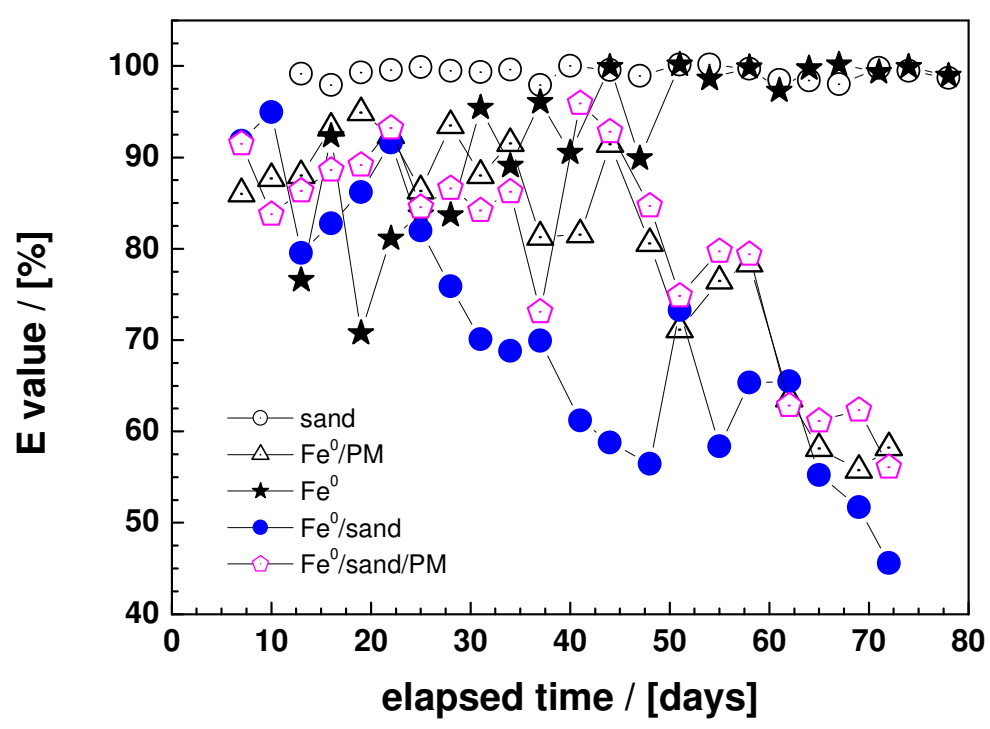


Fig. 4: Permeability

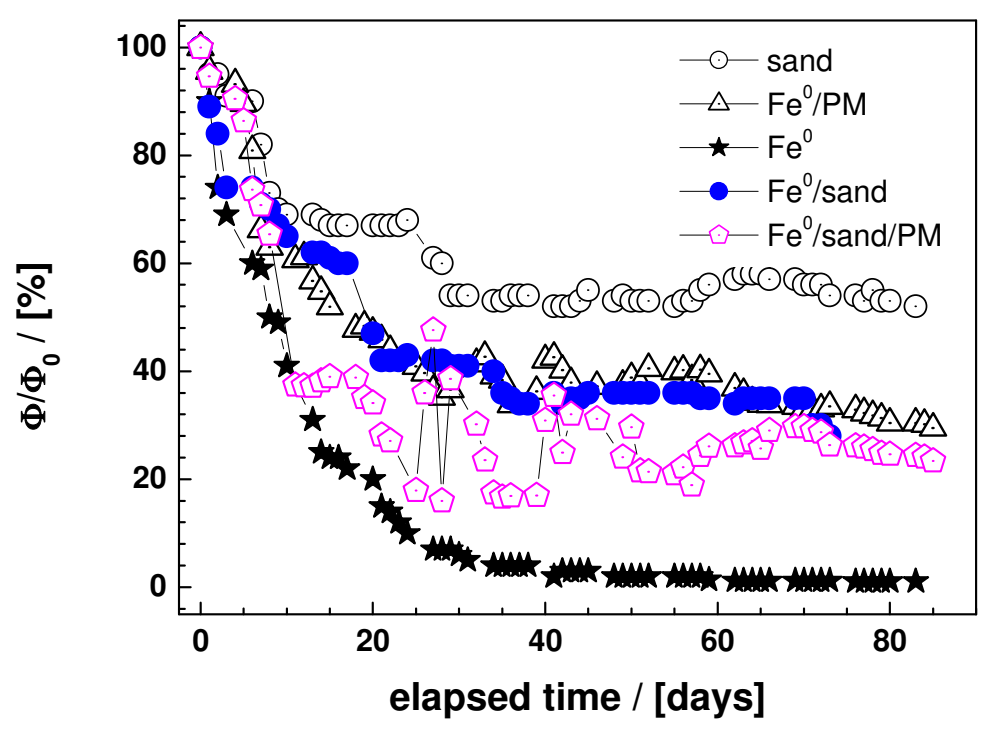




\section{Figure Caption}

Figure 1: Schematic diagram of the experimental design. The five columns represent the investigated systems: (i) pure sand (reference), (ii) pure $\mathrm{Fe}^{0}$, (iii) $\mathrm{Fe}^{0} /$ sand, (iv) $\mathrm{Fe}^{0} / \mathrm{PM}$ and (v) $\mathrm{Fe}^{0} /$ sand/PM. The reference system contains only sand in its 'reactive zone' $\left(\mathrm{H}_{2}\right)$; its height corresponds to that of pure $\mathrm{Fe}^{0}$. The height of each other $\mathrm{H}_{2}$ is proportional to the values in Tab. 2. The dimensions of the columns are: length: $50 \mathrm{~cm}$; diameter: $2.6 \mathrm{~cm}$.

Figure 2: $\mathrm{pH}$ value (a) and iron concentration (b) in the effluent of the columns as a function of time. Experimental conditions: $\mathrm{Fe}^{0}: 65 \mathrm{~g} ;[\mathrm{MB}]=2.0 \mathrm{mg} \mathrm{L}{ }^{-1}$; filling material: sand; column length: $50 \mathrm{~cm}$; column diameter: $2.6 \mathrm{~cm}$. The lines are not fitting functions; they simply connect points to facilitate visualization.

Figure 3: Percent MB discoloration (E value) of the effluent of the columns as a function of time. Experimental conditions: $\mathrm{Fe}^{0}: 65 \mathrm{~g} ;[\mathrm{MB}]=2.0 \mathrm{mg} \mathrm{L} \mathrm{L}^{-1}$; filling material: sand; column length: $50 \mathrm{~cm}$; column diameter: $2.6 \mathrm{~cm}$. The lines are not fitting functions; they simply connect points to facilitate visualization.

Figure 4: Changes of the hydraulic conductivity $\left(\Phi / \Phi_{0}\right)$ in the columns as a function of time. Experimental conditions: $\mathrm{Fe}^{0}: 65 \mathrm{~g}$; $[\mathrm{MB}]=2.0 \mathrm{mg} \mathrm{L}^{-1}$; filling material: sand; column length: $50 \mathrm{~cm}$; column diameter: $2.6 \mathrm{~cm}$. The lines are not fitting functions; they simply connect points to facilitate visualization. 